\title{
Environmental law and the essence of separation of prisoners sentenced to imprisonment: structural analysis
}

\author{
Yulia Golovastova ${ }^{1, *}$ and Ludmila Prikhozhaya ${ }^{1}$ \\ ${ }^{1}$ Academy of the Federal penitentiary service of Russian Federation, 1 Sennaya str., Ryazan, 390000 , \\ Russian Federation
}

\begin{abstract}
The article examines existing approaches and different opinions of scholars-penitentiaries regarding the legal nature of separation of prisoners sentenced to imprisonment. The legal analysis of positions of scholars in the field of criminal executive law, who investigated the essence of separation of prisoners sentenced to imprisonment in various aspects, made it possible to highlight following approaches: 1) principle of institution of execution of punishment in the form of imprisonment; 2) means of ensuring the regime; 3 ) condition for implementation of principle of differentiation; 4) special classification issue; 5) type of classification; 6) intrageneric institution; 7) criminal-executive means of preventing crimes in correctional institutions. The authors come to the conclusion that separation of convicts is an inter-sectoral institution (in a broad sense), and also belongs to the category of internal penal means (in a narrow sense). Arguing this point of view, the general constant and special features of legal institutions and legal means and their application to the subject of research are considered. The authors identify and substantiate the main tasks of separation of prisoners and its functions, which are an external manifestation of its essence and determine the social and legal purpose, functional connection with other phenomena. As a result of study of the legal nature, the author's definition of separate maintenance of those sentenced to imprisonment is proposed, its goals are highlighted and argued.
\end{abstract}

\section{Introduction}

The issues of separation of convicts in places of deprivation of liberty have always belonged to the category of theoretical and applied in the science of criminal-executive (corrective-labor) law, affecting the content of criminal law and criminal executive policy of the state. However, the legal nature of separation of convicts was considered by scientists only in the framework of the study of related legal phenomena. Separate keeping of convicts did not become an independent object of research, possessing distinctive features, purposes, tasks and functions. Given these circumstances, in the science of

\footnotetext{
*Corresponding author: ugolovastova @yandex.ru
} 
criminal executive law, the issue of an ambiguous approach to the concept of structural element under consideration is revealed.

The purpose of the study is to determine the legal nature of separation of prisoners sentenced to imprisonment. Following tasks should be completed:

- Consideration of positions of scholars of criminal-executive law, who investigated the essence of separation of prisoners sentenced to imprisonment, and analysis of approaches to the legal nature of structural element in question;

- Formulation of author's definition of separation of prisoners sentenced to imprisonment;

- Determination of goals of separation of persons sentenced to imprisonment;

- Designation of functions of separation of persons sentenced to imprisonment.

\section{Methods}

The issue of determining the legal nature of separation of convicts has been repeatedly considered by scientists in the framework of study of related legal phenomena in the field of criminal and penal law. At the same time, separate confinement of convicts in correctional institutions (hereinafter - CI) did not become an independent object of research. So, A. Ya. Grishko and A.S. Morozov attributed the separation of convicts to one of the principles of institution of the execution of punishment in the form of imprisonment. Consideration of the issues of attributing the separate detention of convicts to this institution is given attention in the works of E.A. Sizoy and P.A. Meshcheryakov. The study of separation of convicts as a means of ensuring the regime was carried out by B.Z. Malikov, R.Z. Useev, V.E. Yuzhanin. In addition, in the modern science of criminal executive law, there are other studies of different years on this issue, at the same time, determination of legal nature of separation of convicts still remains an unresolved problem.

The methodological basis of the conducted research consisted of various general scientific and private scientific methods of cognition.

At the initial stage of the study, when considering and analyzing the positions of scientists of criminal-executive law, who investigated the essence of separation of prisoners sentenced to imprisonment, formal-logical, dialectical, comparative legal methods of scientific knowledge were used.

At the second stage of the study, when formulating the definition of separation of convicts to imprisonment, the methods of analysis and synthesis, the logical method, and the method of legal modeling were applied.

At the final stage, when defining the goals and functions of separation of convicts, dialectical and systemic-structural methods of cognition were used.

\section{Results}

The study has shown that the separate keeping of those sentenced to imprisonment is understood in a broad sense as an intersectoral legal institution regulated by the norms of criminal and penal law, which has both a multilevel and a multi-stage nature; in a narrow sense, a multifunctional internal criminal-executive tool, implemented within the framework of the institution of execution of imprisonment, serving as a condition for the regime of serving imprisonment, valid from the moment the convicted person is sent to a prison until his release in order to achieve a number of goals of legal regulation of criminalexecutive relations. 


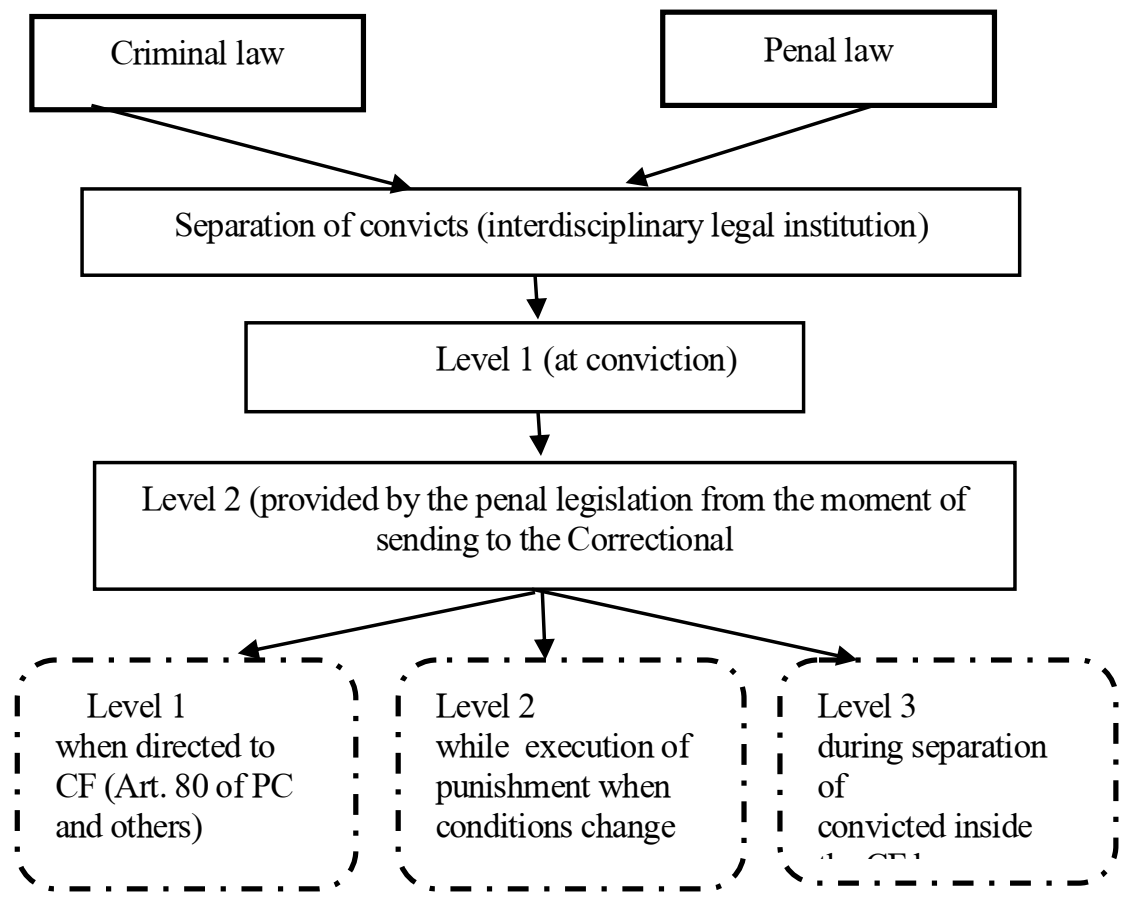

Fig. 1. Separation of convicts in a broad sense.

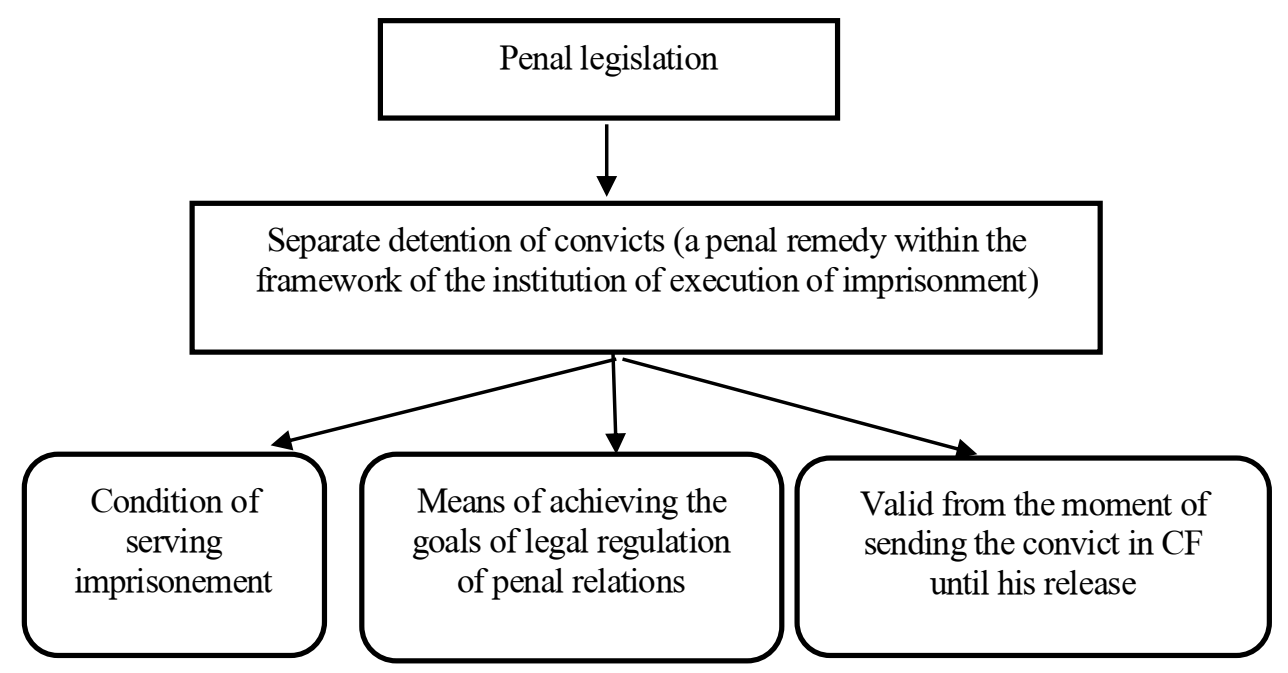

Fig. 2. Separation of convicts in the narrow sense.

\section{Discussion}

The legal nature of separation of convicts has been repeatedly considered by scientists in the framework of study of related legal phenomena in the field of criminal and penal law. 
At the same time, separate keeping of convicts did not become an independent object of research, with distinctive features, purpose, tasks and functions.

Penitentiary scholars who have studied the issues of separation of prisoners sentenced to imprisonment distinguish various approaches to understanding it: 1) principle of institution of execution of punishment in the form of imprisonment (A.Ya. Grishko, A.S. Morozov); 2) means of ensuring the regime (B.Z. Malikov, R.Z. Useev, V.E. Yuzhanin); 3) condition for implementation of principle of differentiation (V.B. Malinin, L.B. Smirnov, I.V. Malysheva); 4) special classification problem (S.M. Savushkin); 5) a kind of classification (V.E. Yuzhanin, D.V. Gorban); 6) intra-clan institute (EA Sizaya, P.A. Meshcheryakov); 7) criminal-executive means of preventing crimes in penitentiary institutions (V.V. Bochkarev).

I. I. Grishko considered the legal nature of separation of convicts from the position of principle of institution of execution of punishment in the form of imprisonment. In his opinion, implementation of this institution is impossible only within the framework of criminal-executive legislation and is provided by a set of fundamental principles governing imprisonment, where one of the fundamental principles was the principle of separation of convicts. According to A.S. Morozov, the principle of separation of convicts in prison is expressed in Art. 80 of Penal Code of Russian Federation.

B.Z. Malikov and R.Z. Useev classify the separation of convicts as a common means of ensuring the regime and consider it as one of the important conditions for ensuring it. This position is confirmed by the opinion of Professor V.E. Southerner, who considers the separation of convicts as a means of ensuring the regime in the correctional institution.

When considering the legal nature of separation of prisoners sentenced to imprisonment, it should be pointed out that in the domestic penal law there are disagreements regarding its comparison with phenomena similar in functional purpose, in particular, with the differentiation of execution of sentences and classification of convicts. We are in solidarity with the authors who attribute classification to the method of differentiating the execution of punishment. It is also not controversial that scientifically grounded criteria for classification of convicts form the basis for implementation of differential corrective action. At the same time, the relationship of separation with these concepts is ambiguous, determining the need to consider these phenomena in the theory and practice of investigated tool.

In his research, S.M. Savushkin points out that the institution of classification of convicts influences the construction of prison system, ensuring the separation of convicts different in terms of the degree of social danger and the nature of their behavior.

According to V. B. Malinin and L.B. Smirnov, the principle of differentiation is manifested in the separate keeping of women, men and minors (part 3 of article 73 of the Criminal Code of Russian Federation). In addition, the differentiation of execution of punishments is implemented when classifying convicts and distributing them by type of correctional institution. The principle of individualization of execution of punishment is based on taking into account the individual characteristics of personality of the convict and his behavior.

I.N. Pavlov, points out that "classification of prisoners sentenced to imprisonment and their separation is not based on the criminal-legal characteristics of perpetrators, but mainly on penitentiary and psychological and pedagogical signs, because the purpose of execution of punishment is the resocialization of convicts".

According to I.V. Malysheva, criminal-executive classification of convicts pursues the goal of differentiating the execution and serving of sentences, but already through a more in-depth division. At the same time, there is a differentiation of execution of punishment depending on requirements for separation of certain categories of convicts, including in order to exclude the influence of some prisoners on others. 
We believe that the study of legal nature of separation of convicts in the context of correlation between the principle of differentiation and individualization of execution of sentences should begin with a general description of this principle. To differentiate and individualize the execution of sentences, the idea is to establish optimal conditions for serving a sentence with the use of necessary amount of punitive and educational influence, taking into account the nature and severity of the crime committed, the personality of the convicted person, as well as behavior during the period of serving the sentence. Thus, the position that the separation of content acts as a condition for achieving the goals of the principle of differentiation and individualization of the execution of punishments seems to be correct.

According to the point of view of V.E. Yuzhanin and D.V. Gorban, main purpose of the classification is to create optimal conditions for differentiating punitive and educational impact on various categories of convicts. Separate content, at the same time, is a kind of classification, but has a different purpose - to exclude the influence of the most dangerous, negative part of convicts from other persons to the maximum possible extent. So, for example, according to Art. 58 of the Criminal Code of Russian Federation correctional colonies of general, strict and special regime are determined on the basis of the classification of convicts according to the established criteria. The separation of convicts is carried out within the framework of established classification in accordance with the requirements of the law.

E.A. Sizaya expressed a point of view different from other authors regarding the legal nature of separation of prisoners sentenced to imprisonment, according to which this phenomenon belongs to the number of legal institutions. In her research, she classified the institutions of criminal executive law, highlighting the general, clan and intra-clan institutions. In her opinion, tribal institutions are related to all types of punishment, tribal institutions regulate the execution of each type of punishment, and intra-clan institutions, respectively, are carried out within the framework of tribal institutions. Based on the above, E.A. Sizaya refers to the separate maintenance of different categories of convicts according to the type of sentence serving regime to the intra-clan institution. This position was further supported by P.A. Meshcheryakov.

As for the opinion of E.A. Sizoy and P.A. Meshcheryakov, we do not fully share the categorization of separation of convicts among the intra-clan institutions of criminal executive law. In our opinion, there is no doubt about the existence of general, clan and intra-clan institutions that determine and regulate the execution of various types of punishments at all stages of their implementation. However, belonging to a certain level can be determined only through the prism of certain characteristics. Let's consider their implementation for separation of prisoners sentenced to imprisonment.

Each legal institution has its own internal organization, its own structure. In particular, the characteristic features of the elements (prescriptions) of a legal institution are their equality, heterogeneity, as well as the unification of norms by stable, regular relationships expressed in a legal structure. Considering the separate content of convicts as an institution of law, it should be noted that it includes several one-order normative provisions (different categories of convicts are indicated, formed on the basis of different characteristics, which are equal in their own way, for the further application of the appropriate volume of corrective action, creating conditions and the order of detention during the period of serving the sentence). The multifaceted impact on public relations in the area under consideration is manifested in the current norms of criminal and penal law governing the procedure for separate detention of each category of convicts, the order and conditions created for them during the period of serving a sentence of imprisonment. Despite the fact that, within the framework of criminal and penal legislation, rules and regulations of the institution of separation are located remotely from each other, there is a general tendency in the 
consolidation of one or another category of convicts, of one type or another of penitentiaries on the basis of general requirements enshrined in Art. 80 of Penal Code.

At the same time, considering the signs of a legal institution, it should be noted that this element of law has a sectoral purity. At the same time, when regulating the separation of prisoners sentenced to imprisonment, two areas of law are involved.

Considering the separation of prisoners sentenced to imprisonment as an interbranch institution of law, it should be noted the direct influence of norms of the branches of law of criminal legal complex during its formation, which act as fundamental and are reflected at all stages (levels) of its implementation. Thus, the primary separation of convicts (the first level) is regulated by the norms of criminal law and is carried out by the court when a conviction is passed. In accordance with Art. 58 of Criminal Code of Russian Federation, when appointing the type of CF, the nature and degree of social danger of the crime, the personality of the perpetrator, which are determined on the basis of other norms of criminal legislation (Articles 15, 18, 20, 22, 25 of Criminal Code of Russian Federation, etc.) are taken into account. Further regulation of the execution of punishment in the form of imprisonment (second level) occurs within the framework of criminal executive law, creating the most favorable conditions for increasing the efficiency of penitentiary institutions and achieving the goals of criminal executive legislation. Note that the influence of cross-sectoral institutions can be traced in the process of executing punishment - when changing the type of prison. However, in this case, the borrowing of branches of criminal law is reborn and begins to regulate criminal-executive legal relations within the framework of the institution of imprisonment, being the norms of criminal-executive law. It should be pointed out that, on the basis of the norms of penal legislation, additional steps (stages) are envisaged: 1) when a convict is sent to a specific prison, when the separate keeping of different categories of convicts is taken into account (Article 80 of Criminal Code, etc.); 2) in the process of execution of the sentence, when the behavior of the convicted is taken into account (the separation occurs when the conditions for serving the sentence change). In penitentiary institutions, the third stage of the division of convicts into groups is carried out on the basis of psychological, pedagogical, criminological, social and other criteria. This is the distribution of convicts within the penitentiary by detachments, carried out by the administration of the institution.

Thus, in our opinion, the attribution of institution of separation of convicts to imprisonment to the number of intra-clan institutions of criminal-executive law, as E.A. Sizaya and P.A. Meshcheryakov is not possible due to its intersectoral affiliation. At the same time, from the moment a convict is sent to a correctional institution, separation of convicts is not an independent institution of law, but is carried out within the framework of the institution of imprisonment.

Based on the foregoing, we consider it expedient to refer the separation of convicts to imprisonment in a broad sense to an intersectoral legal institution regulated by the norms of criminal and penal law, which has both a multilevel and a multi-stage nature.

Consideration of separation of prisoners sentenced to imprisonment in the narrow sense should be carried out within the framework of the second level of an interdisciplinary institution - on the basis of norms of criminal executive legislation, with an indication of belonging to a certain structural element of law. For this, it seems expedient to cite the position of V.V. Bochkarev, in whose opinion the separation of convicts is one of the promising criminal-executive means of preventing crimes in penitentiaries, which has integrated properties and is aimed at correcting convicts and providing them with a preventive effect. For the sake of fairness, we note that this point of view seems to be quite reasonable and interesting. For its argumentation, it is necessary to understand the concept of "legal means" and its features in relation to the penal sphere. 
Moving on to further argumentation of the belonging of separation to legal means, it is advisable to ask the question: "What are the signs that characterize the separation of prisoners sentenced to imprisonment in the context of its understanding as an internal criminal-executive means?"

First of all, let us designate that the implementation of this legal remedy is ensured by the state in the person of institutions executing criminal sentences in the form of imprisonment. At the same time, as extra-legal, independent, isolated functioning of the considered feature is unacceptable, it should be considered taking into account the normative regulation of separation of convicts. These signs give it legality, allowing it to act as an instrument of pressure on subjects that impede the implementation of subjective rights and legal obligations. Thus, the normative reflection of separation is manifested in the norms of criminal and penal legislation that establish the type of penitentiary institution, the regime for serving sentences, and also fixes mandatory requirements on the basis of which the isolation and separation of certain groups of convicts is carried out (Article 58 of the Criminal Code of Russian Federation, Article 74, 80 of the Penal Code of Russian Federation).

It is also important that the presence of legal consequences is inherent in the separation of convicts. Its implementation predetermines its impact on criminal-executive relations, the end result of which is to bring the models of lawful behavior of the participants in relations in accordance with the established regulatory legal acts in the implementation of punishment in the form of imprisonment. At the same time, legal means always occupies an intermediate position in the triad "end - means - result". The essence of this feature for separation of convicts lies in the fact that it is implemented within the framework of general goals of penal legislation, being an instrument for achieving their final result.

The next sign of separation of convicts as a penitentiary tool is manufacturability implementation of activities based on its rational division into procedures and operations with their subsequent coordination and synchronization and the choice of optimal means and methods of their implementation. This feature means that on the basis of separate content, differentiation and division of the process of execution of the sentence in the form of imprisonment is carried out into stages.

In general, with the help of separate keeping of those sentenced to imprisonment, the interests of the subjects of criminal-executive relations are satisfied and achievement of socially significant goals is ensured, in other words, goal-rationality is a sign of this criminal-executive tool.

In addition to general goals, this tool has special goals, as well as tasks and functions that make it possible to reveal its essence in full.

In our opinion, the goals of the separation of convicts should include: special (private) and general prevention of new crimes; differentiation of execution of punishment for various categories of convicts; safety of convicts, staff and other persons; exclusion of negative impact from certain categories of convicts; health protection of convicts, staff and other persons.

The implementation of the goal of general prevention is carried out both through a system of restrictions and through measures of educational and corrective influence on certain categories of convicts who are not among the violators of the regime. It is important to note that within the framework of achieving this goal, it becomes possible to single out the most characteristic features of various convicts in order to predict their possible behavior during the period of serving their sentence and after their release from prison. A special (private) warning is expressed in fixing the type of penitentiary institution and the regime of detention for the convicted person, based on the degree of public danger and the degree of danger of the crime committed. 
Ensuring the differentiation of execution of punishment for various categories of convicts is one of the leading goals of separation. The allocation of different categories of convicts to provide a certain differentiated impact during the execution of a sentence of imprisonment changes under the influence of objective conditions for development of social relations, the state and dynamics of crime, the use of various measures and methods of fighting it. The consolidation of scientifically grounded categories of convicts is the basis for effective provision of corrective and educational influence, as well as the rational use of various amounts of punitive and educational influence on convicts.

The implementation of security of convicts, personnel and other persons is carried out within the framework of achieving the general goal of imprisonment - ensuring the security of the penal system. The security of the penitentiary system depends on the distribution of convicts in different types of penitentiaries, different conditions of detention within one institution, as well as the use of punitive and educational measures during the period of serving a sentence of imprisonment.

The purpose of the separation of convicts, referred to as the exclusion of negative impact on the part of certain categories of convicts, is related to the purpose of ensuring the safety of convicts, staff and other persons. At the same time, when considering it, it is important to point out that if the latter establishes protection guarantees for vulnerable categories of convicts, then the compared goal determines the allocation and isolation of the most dangerous categories of convicts, from the point of view of criminal-legal and psychological-pedagogical grounds. The exclusion of negative impact on the part of certain categories of convicts provides for a system of measures in which it becomes difficult to implement their impact on other categories of convicts.

In addition to the above mentioned, one of the socially significant goals is the protection of health of convicts, staff and other persons, which consists in ensuring timely provision of preventive and medical care to prevent the spread of viral and infectious diseases in penitentiaries.

The goals of separation of prisoners sentenced to imprisonment are achieved through the tasks set. We refer to the main tasks of the separate detention of convicts: 1) formation of conditions for ensuring a differentiated volume of punitive and educational influence; 2 ) establishment of various conditions for serving the sentence and the degree of isolation of convicts, depending on the behavior and danger of the individual; 3) ensuring sanitary and hygienic and anti-epidemic standards and requirements; 4) creation of conditions for timely provision of medical and preventive and health care; 5) application of various amounts of legal restrictions based on criminal experience and negative personality; 6) ensuring the safety of convicts, personnel and other persons, as well as identifying and developing effective measures aimed at maintaining vulnerable categories of convicts; 7) creating conditions for achieving the objectives of classification; 8) implementation of measures aimed at achieving general and special (private) prevention of commission of crimes; 9) creating conditions for implementation of requirements of the regime.

Any legal means has a set of certain functions that act as an external manifestation of its essence and determine its social and legal purpose, connection with other phenomena. The main function of any legal means is to achieve the goals of legal regulation: to ensure the unhindered achievement by the subjects of their interests, guaranteeing their legal satisfaction, aimed at a socially significant result. It is advisable to refer to the main functions of separation of convicts: punitive, incentive, corrective, preventive, protective, provisional (as general), security (private). At the same time, the originality of relations, regulated by the separation of convicts, their diversity determines the specificity of functions of the considered means. Let's move on to their consideration.

We believe that the punitive function is to ensure the implementation of various amounts of punitive measures when kept in different types, regimes of penitentiary 
institutions, and conditions for serving a sentence (legal restrictions, living conditions of detention, etc.).

The incentive function is manifested in the ability to provide a special legal impact on behavior of positively characterized convicts. In other words, this function is expressed in the creation of improved conditions of detention for positively characterized convicts and a change in the type of prison, acting as an incentive for law-abiding behavior and a responsible attitude towards work.

The corrective function consists in the use of remedies based on the degree of criminal and pedagogical neglect, attitude to the committed criminal act and the punishment imposed by the court, as well as the creation of conditions for law-abiding behavior.

The preventive function is manifested in a set of measures to ensure the deprivation of physical ability to commit a new crime in the penitentiary (isolation), as well as to implement the systematic application of measures of punitive, educational and corrective influence aimed at preventing the commission of crimes after release from prison.

The protective function has a sanctioning effect on the convict, depending on his behavior during the period of serving a sentence of imprisonment.

We believe that the security function is expressed in the "statement of norms of criminal executive law governing the life of convicts". For the process of separation of convicts, this function is expressed in the establishment of certain material and living conditions, depending on the type of prison regime and conditions for serving imprisonment.

Finally, the function of ensuring security includes implementation of means and methods (identification, separation and isolation) aimed at preventing violence (physical, moral, mental) against convicts, personnel and other persons, as well as illegal actions that threaten their personal safety and security.

\section{Conclusion}

Based on the study of the legal nature of separation of convicts, it became possible to determine the role and place of this element in the structure of law. Theoretical comprehension of its systemic qualities made it possible to formulate the author's definition of "separation of prisoners sentenced to imprisonment", which should be understood as: in a broad sense, an intersectoral legal institution regulated by the norms of criminal and penal law, which has both a multilevel and a multi-stage nature; in a narrow sense, a multifunctional internal criminal-executive tool, implemented within the framework of the institution of execution of imprisonment, acting as a condition for the regime of serving imprisonment, acting from the moment a convict is sent to a prison until his release in order to achieve a number of goals of legal regulation of criminal-executive relations.

\section{References}

1. A.Ya. Grishko, Society and Law 4(50), 334-338 (2014)

2. A.S. Morozov, Criminal executive system today: interaction of science and practice: materials of the All-Russian scientific and practical conference (Novokuznetsk, 2017)

3. E.A. Sizaya, Criminal executive law 6, 73-76 (2008)

4. P.A. Meshcheryakov, Ius publicum et privatum 1, 40-42 (2018)

5. V.E. Yuzhanin, Bulletin of the Kuzbass Institute 4(33), 102-110 (2017)

6. Yu.A. Golovastova, Penal law as a branch of Russian law: subject, method, sources, system: monograph (M., 2019) 
7. N.I. Polishchuk, I.S. Lebeshev, L.E. Prikhozhaya, I.Kh. Dakashev, I.A. Smirnov, Revista Dilemas Contemporáneos: Educación, Política y Valores (2020)

8. I.V. Malysheva, Bulletin of St. Petersburg University of Russia 3(67), 55-58 (2015)

9. S.M. Savushkin, Bulletin of Economics, Law and Sociology 1, 166-169 (2016)

10. V.E. Yuzhanin, L.E. Hallway, Bulletin of the Kuzbass Institute 4(37), 117-124 (2018)

11. S.M. Savushkin, Bulletin of the institute: crime, punishment, correction 3(35), 30-33 (2016)

12. V.V. Bochkarev, Criminal executive means of implementing the private preventive function of punishment in the form of imprisonment: dis. ... Cand. jurid. Sciences: 12.00.08 (Nizhny Novgorod, 2018)

13. A.V. Kuzmin, Theory and practice of the restoration of rights 11, 1-10 (2013)

14. A.A. Ananyeva, Bulletin of the Saratov State Law Academy 1(108), 88-94 (2016)

15. Ya.A. Margulyan, Social technologies of society management: regional level $(\mathrm{SPb}$, 2010)

16. G.S. Belyaeva, Administrative and municipal law 3(87), 306-312 (2015)

17. V.F. Lapshin, S.A. Korneev, E3S Web of Conferences 135, 04063 (2019) DOI: 10.1051 / e3sconf / 201913504063

18. A.A. Brovkina, V.E. Vezlomtsev, S.S. Zakharova, O.A. Shuranova, Yu.V. Truntsevsky, E3S Web of Conferences 135, 04066 (2019) DOI: 10.1051 / e3sconf / 201913504066 